\title{
Pelatihan Kiat Membangun Karakter Anak ${ }^{1}$
}

\author{
Radhiya Bustan ${ }^{1}$, Nila Fitria ${ }^{2}$ \\ ${ }^{1,2}$ Program Studi Psikologi, Fakultas Psikologi dan Pendidikan, Universitas Al-Azhar Indonesia, \\ Jl.Sisingamangaraja, Kompleks Masjid Agung Al Azhar, Kebayoran Baru, Jakarta Selatan 12110 \\ Penulis untuk Korespondensi/Email: radhiya bustan@yahoo.com
}

\begin{abstract}
Abstrak - Dampak negatif dari globalisasi perlu diantisipasi sejak dini. Mulai dari struktur terkecil dalam masyarakat, yaitu keluarga dengan penanaman karakter sejak dini. Perlu kiranya orang tua, guru, maupun anggota masyarakat untuk memahami bagaimana membangun karakter Islami pada anak. Untuk itu, kegiatan pengabdian masyarakat ini berupa pelatihan dengan tema "Kiat Membangun Karakter Anak" diberikan kepada orangtua dan guru TK Raudhatul Azhar. Tujuan kegiatan ini untuk memberikan pemahaman kepada orangtua terkait pendekatan psikologis sesuai masa perkembangan anak, agar orangtua dapat menjalankan perannya dalam menanamkan karakter positif dan Islami pada anak. Karakter dalam Islam disebut juga dengan akhlak. Akhlak termasuk didalamnya adab yang meliputi pembiasaan, keteladanan, dan disiplin. Adapun materi pelatihan yang diberikan untuk orangtua berkaitan dengan "Kiat Membangun Karakter Anak Ditinjau dari Aspek Agama dan Psikologis", dan materi yang diberikan untuk guru berkaitan dengan "Pembelajaran Moral dan Perilaku Anak Usia Dini". Hasil pelatihan menggambarkan bahwa pelatihan terkait "Kiat Membangun Karakter Anak" dibutuhkan oleh orangtua, terlihat dari hasil evaluasi bahwa hampir $90 \%$ orangtua merasa memperoleh pemahaman terkait membangun karakter anak, walaupun baru sekitar $85 \%$ orangtua yang sudah mulai menerapkan materi tersebut. Begitu pula dengan hasil evaluasi yang diperoleh dari guru TK Raudlatul Azhar, bahwa 90\% guru TK memperoleh pengetahuan tentang rancangan dan pelaksanaan kurikulum berbasis karakter dari materi pelatihan. Berdasarkan hasil tersebut, diperoleh masukan agar pada kegiatan selanjutnya lebih banyak ditambahkan materi praktek dan tugas rumah yang dievaluasi secara berkala.
\end{abstract}

Kata Kunci - Membangun Karakter Anak, Pendekatan Psikologis, Pembelajaran Moral dan Perilaku

Abstract - The negative impact of globalization should be anticipated early. Starting from the smallest structures in society. It would need to parents, teachers, and community members to understand how to build an Islamic character to children. For that, this public service activities such as training on the theme "Ways to Build Character in Early Childhood" are given to the parents and teacher in kindergarten Raudhatul Azhar. Its objective is to provide insight to parents related psychological approaches appropriate future development of the child, so parents can fulfill their role in instilling positive and Islamic character in children. Characters in Islam is also called morals. Morals including adab include habituation, modelling, and discipline. The training materials provided to a parent related to "Ways to Build Character in Early Childhood - Psychological and Religion Aspects". And the material given to the teachers is about "Moral and Behavior Education in Early Childhood". The results illustrate that the training are required by parents, seen from the results of the evaluation that nearly $90 \%$ of parents feel gain related knowledge to build the character of children, although only about $85 \%$ of parents who have started to apply the material. Similarly, the evaluation results obtained from kindergarten teacher Raudlatul Azhar, that $90 \%$ of kindergarten teachers to acquire knowledge about the design and implementation of curriculum-based character of the training

\footnotetext{
${ }^{1}$ Paper ini telah diseminarkan di seminar internasional " International Conference On Education And Training” Universitas Negeri Malang pada tanggal 04-06 November 2016
} 


\section{materials. Based on these results, obtained input for the next activity focused on material practice and chores are evaluated regularly.}

\section{Keyword - Building Child Character, Psychological Approach, Moral Learning and Behavior}

\section{PENDAHULUAN}

\section{Latar Belakang}

Ememberikan perubahan besar dalam kehidupan masyarakat, diantaranya perubahan sosial budaya dan agama. Sebagian generasi muda hidup dengan dunia pada zaman "mereka" dan mengenyampingkan nilai-nilai budaya dan moral yang sudah dianut sejak lama oleh pendahulunya. Hal ini menimbulkan berbagai kesenjangan dalam lingkungan masyarakat.

Dampak negatif dari globalisasi ini perlu diantisipasi sejak dini. Tentunya dari struktur terkecil dalam masyarakat, yaitu keluarga. Keluarga merupakan sebuah "sistem", sehingga memerlukan kepedulian masing-masing anggotanya untuk saling memberikan kehidupan yang nyaman dan harmonis bagi seluruh anggota keluarga. Penerapan nilai-nilai yang dimulai dari keluarga, akan mengantarkan masing-masing anggotanya untuk siap menghadapi lingkungan yang lebih luas dan berbagai tantangan perkembangan zaman seperti globalisasi saat ini. Untuk itu, penanaman karakter sejak dini ini sangat diperlukan agar dapat meminimalisir dampak negatif dari gempuran budaya asing yang masuk, dan juga diperlukan pendidikan moral dan agama yang kuat agar masyarakat mempunyai pegangan dalam menjalani kehidupan.

Pendidikan karakter sejak dini dalam keluarga sangat dibutuhkan. Ibarat bangunan, tentunya fondasi yang kuat akan membuat bangunan tersebut dapat bertahan dari angin badai yang menerjang. Semakin dini kita menanamkan karakter kepada anak, semakin kuat tertanamnya di dalam diri mereka. Pendidikan dimulai dari sebelum dilahirkan dan terus berlanjut sampai anak dewasa.

Terjadinya krisis moral dimana-mana bisa jadi disebabkan karena kita belum memahami bagaimana cara yang tepat, waktu yang tepat, dan pendekatan yang efektif ketika kita harus menanamkan karakter positif kepada anak kita. Tentunya perlu memahami mereka terlebih dahulu, bagaimana perkembangan fisik maupun psikologis mereka. Ketika kita sudah memahami hal tersebut, kita akan lebih mudah untuk menanamkan karakter baik atau unggul kepada anak kita. Dia akan berusaha melakukan hal-hal yang diajarkan oleh agama, berbuat yang terbaik untuk dirinya, sesama, lingkungan, bangsa dan negara. Kita juga akan mudah memotivasi mereka untuk mengoptimalkan potensi (pengetahuan) dirinya dan disertai dengan kesadaran, emosi dan motivasinya, sehingga mewujudkan generasi muda yang mempunyai imtak dan iptek.

Berkaitan dengan hal yang diuraikan di atas, perlu kiranya orang tua, guru, maupun anggota masyarakat untuk memahami bagaimana membangun karakter Islami pada anak-anak kita. Hal apa yang harus kita pahami dan perhatikan agar dapat melakukannya dengan maksimal. Tentunya setelah mengetahui, perlu adanya tekad yang kuat untuk melaksanakannya. Hal tersebut akan dibahas dalam pelatihan "Kiat Membangun Karakter Anak".

Pelatihan ini merujuk kepada penelitian terdahulu yang sudah kami lakukan, yaitu penelitian "Harapan Orangtua dalam Mendidik Anak Usia Dini" dimana hasil penelitain menyatakan $80 \%$ orangtua menghendaki pelatihan dengan materi perkembangan anak, pelatihan tersebut sudah kami laksanakan pada kegiatan pengabdian masyarakat tahun 2014. Hasil lain dari penelitian tersebut menunjukkan bahwa sebagian besar orangtua menyatakan bahwa mereka sangat membutuhkan kegiatan yang bertujuan mempelajari cara-cara baru tentang berinteraksi yang positif dengan anakanak mereka. Sehubungan dengan hal tersebut, maka kami ingin melanjutkan kegiatan pengabdian masyarakat tersebut dengan materi terkait "Kiat Membangun Karakter Anak" yang diberikan kepada orangtua dan guru TK Raudhatul Azhar. 


\section{Tujuan}

Tujuan kegiatan pengabdian masyarakat ini adalah untuk memahami apakah pelatihan Kiat Membangun Karakter anak dapat menimbulkan perubahan perilaku bagi orangtua dalam membangun karakter anak.

\section{Perumusan Masalah}

Adapun perumusan masalah dalam kegiatan pengabdian masyarakat ini adalah:

Apakah Kegiatan Pelatihan "Kiat Membangun Karakter Anak" di TK Raudlatul Azhar dapat efektif sebagai sarana bagi orangtua dan guru dalam memberikan pendidikan karakter sejak dini?

\section{Ruang Lingkup}

Adapun bentuk kegiatan adalah pelatihan "Kiat Membangun Karakter Anak".

Pelatihan ini akan diberikan kepada 90 orangtua yang mempunyai anak yang bersekolah di TK Raudlatul Azhar dan 12 orang gurunya. Materi-materi yang disampaikan akan dikemas dalam bentuk modul.

\section{Kontribusi}

Adapun manfaat kegiatan pengabdian masyarakat ini antara lain:

1. Orangtua dan guru

- Memperoleh pengetahuan mengenai cara membangun karakter anak.

- Dapat mempraktekkan langsung pengetahuan yang diperoleh setelah mengikuti pelatihan

2. Mahasiswa

- Belajar menerapkan konteks teoritis dan fakta ke dalam praktek (theory in to action)

- Melatih kepekaan terhadap masalahmasalah yang terjadi di dalam masyarakat

3. Dosen

- Mewujudkan salah satu tri dharma perguruan tinggi, yaitu pengabdian masyarakat

- Mengasah empati dan kepekaan terhadap masalah yang terjadi di masyarakat

4. Fakultas Psikologi dan Pendidikan

- Memperluas akses jaringan di dalam masyarakat
- Sarana untuk mempromosikan Fakultas Psikologi dan Pendidikan

\section{KERANGKA TEORI}

\section{Pengertian Keluarga}

Keluarga adalah sekumpulan orang dengan ikatan perkawinan, kelahiran, dan adopsi yang bertujuan untuk menciptakan, mempertahankan budaya, dan meningkatkan perkembangan fisik, mental, emosional, serta sosial dari tiap anggota keluarga (Duvall dan Logan, 1986).di dalam keluarga di bangun perkembangan fisik, mental, emosional, serta sosila tiap anggota keluarga. Sehingga keluarga dapat membangun suatu kesatuan yang utuh dalam perkembangannya.

Lain halnya menurut Baiolon dan Maglaya, mengatakan keluarga Keluarga adalah dua atau lebih individu yang hidup dalam satu rumah tangga karena adanya hubungan darah, perkawinan, atau adopsi. Mereka saling berinteraksi satu dengan yang lain, mempunyai peran masing-masing dan menciptakan serta mempertahankan suatu budaya (Bailon dan Maglaya,1978 ). Hubungan darah menghubungkan akan adanya hubungan darah, perkawinan, dan perkawinan. Menurut Departemen Kesehatan menjelaskan bahwa Keluarga merupakan unit terkecil dari masyarakat yang terdiri dari kepala keluarga dan beberapa orang yang berkumpul dan tinggal di suatu tempat di bawah satu atap dalam keadaan saling ketergantungan. Untuk itu keluarga berperan sebagai pendidik yang pertama dan utama dalam pendidikan anak yang di dalamnya memiliki ketergantungan antara satu dengan yang lain.

\section{Pengertian Karakter}

Pada era 2000 ini, pendidikan di Indonesia diramaikan dengan adanya pendidikan karakter. Kita mengetahui bahwa karakter di dalam agama Islam sering kita kenal dengan akhlak. Menurut Lickona, karakter berkaitan dengan konsep moral (moral knonwing), sikap moral (moral felling), dan perilaku moral (moral behavior). Berdasarkan ketiga komponen ini dapat dinyatakanbahwa karakter yang baik didukung oleh pengetahuan tentang kebaikan, keinginan untuk berbuat baik, dan melakukan perbuatan kebaikan. Sehingga pendidikan 
karakter dapat diartikan dapat didefinisikan sebagai segala usaha yang dapat dilakukan untuk mempengaruhi karakter siswa.

Tetapi untuk mengetahui pengertian yang tepat, dapat dikemukakan di sini definisi pendidikan karakter yang disampaikan oleh Thomas Lickona. Lickona menyatakan bahwa pengertian pendidikan karakter_adalah suatu usaha yang disengaja untuk membantu seseorang sehingga ia dapat memahami, memperhatikan, dan melakukan nilai-nilai etika yang inti.

Sedangkan menurut Kertajaya, (2010) karakter adalah ciri khas yang dimiliki oleh suatu benda atau individu. Ciri khas tersebut adalah asli dan mengakar pada kepribadian benda atau individu tersebut, serta merupakan "mesin" yang mendorong bagaimana seorang bertindak, bersikap, berucap, dan merespon sesuatu .kepribadian yang harus dibangun sejak usia dini, diintegrasikan ke dalam kurikulum PAUD yang memiliki 18 nilai karakter, yaitu :

1. Religius,

2. Jujur,

3. Toleransi,

4. Disiplin,

5. Kerja Keras,

6. Kreatif

7. Mandiri

8. Demokratis

9. Rasa Ingin Tahu

10. Semangat Kebangsaan

11. Cinta tanah air

12. Menghargai prestasi

13. Bersahabat/komunikatif

14. ,Cinta Damai

15. Gemar membaca

16. Peduli lingkungan,

17. Peduli social,

18. Tanggung jawab.

Kemudian menurut Suyanto, karakter adalah cara berpikir dan berperilaku yang menjadi cirri khas setiap individu untuk hidup dan bekerjasama, baik dalam lingkungan keluarga, masyarakat, bangsa dan negara. Individu yang berkarakter baik adalah individu yang bisa membuat keputusan dan siap mempertanggungjawabkan setiap akibat dari keputusan yang dibuat (Ansori, 2007).
Menurut Sahrudin (2007), upaya pembentukan karakter bagi anak sangatlah penting. Sebab, hal itu bertujuan membentuk pribadi-pribadi yang berakhlak mulia, toleran, senang membantu, gotong-royong, bermental tangguh dan kompetitif, serta senantiasa memiliki ketertarikan terhadap ilmu pengetahuan. Semua kemampuan ini dilandasi oleh keimanan dan ketakwaan kepada Tuhan Yang Maha Esa.

Nilai-nilai karakter tersebut dikembangkan di setiap kompetensi yang ada di dalam kegiatan belajar mengajar di sekolah. Tetapi tidak dapat terbentuk karakter yang baik apabila tidak dilakukan di dalam pendidikan informal yaitu keluarga. Orangtua berperan besar dalam membentuk karakter anak-anak yang bersifat unik.

\section{METODE INTERVENSI (PELATIHAN)}

Metode dalam kegiatan pengabdian masyarakat ini adalah dengan pelatihan sebagai sarana intervensi. Intervensi adalah suatu tindakan yang menghasilkan perubahan atau usaha untuk merubah seseorang, populasi, atau organisasi yang menjadi subyek evaluasi (Øvretveit,1998). Adapun tujuan dari intervensi adalah untuk menghasilkan suatu perubahan serta membuat perubahan dalam hidup seseorang (Øvretveit,1998). Bentuk intervensi yang dilakukan adalah pelatihan yang merupakan tahap berikutnya dari implementasi hasil penelitian terkait "Harapan Orangtua dalam Mendidik Anak Usia Dini”.

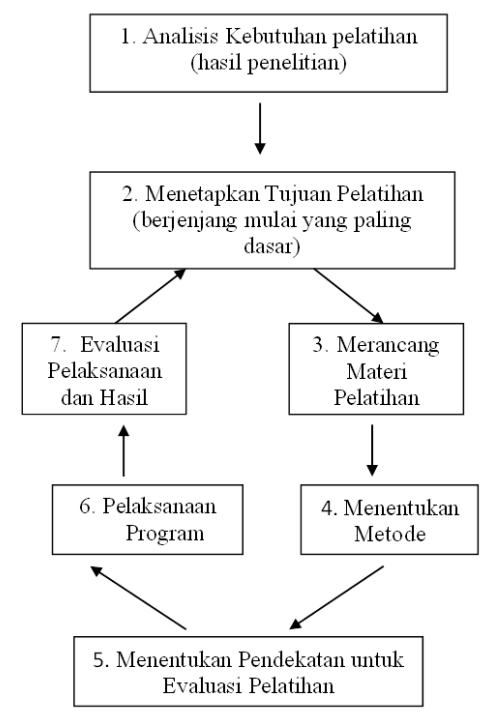

Gambar 1. Desein Pelatihan 


\section{SOSIALISASI DAN PROFIL RESPONDEN}

\section{Sasaran Khalayak}

Pelatihan "Kiat Membangun Karakter Anak" ini dilaksanakan di TK Raudhatul Azhar, Kreo kota Tangerang. Adapun jumlah murid TK Raudlatul Azhar 90 anak dan jumlah guru 12 orang. Untuk itu, sasaran kegiatan pengabdian masyarakat ini adalah orangtua dan guru. TK Raudlatul Azhar merupakan taman kanakkanak yang berdiri pada tahun 1993 yang awalnya tenaga pendidik berasal dari ibu-ibu PKK. Peserta didiknya berasal dari kalangan ekonomi lemah, dimana latar belakang orangtua bekerja sebagai tukang ojek, tukang jahit, tukang cuci, dan adapula yang bekerja sebagai pegawai.

\section{Jadwal Pelaksanaan}

Kegiatan ini dilakukan selama 5 bulan, yang semula dimulai bulan Desember 2015 - April 2016, terjadi perubahan waktu mulai Februari 2016 - Juni 2016 karena bersamaan dengan libur semester awal di TK Raudhatul Azhar. Adapun tahapan pelaksanaan kegiatan adalah sebagai berikut:

\section{Persiapan}

Kegiatan ini dimulai dengan mempersiapkan materi-materi yang berkaitan dengan pelatihan yang akan diberikan. Untuk orangtua, materi yang dipersiapkan berkaitan dengan "Kiat Membangun Karakter Anak Ditinjau dari Aspek Agama dan Psikologis". Adapun materi yang akan diberikan untuk guru berkaitan dengan "Pembelajaran Moral dan Perilaku Anak Usia Dini". Metode dan materi yang diberikan merujuk kepada penelitian terdahulu yang sudah kami lakukan, yaitu penelitian "Harapan Orangtua terhadap Pendidikan Keorangtuaan".

\section{Pelaksanaan}

Pelaksanaan pelatihan ini dimulai pada akhir Maret 2016 di TK Raudlatul Azhar, Kreo Kota Tangerang. Media yang digunakan adalah papan tulis, spidol, LCD Proyektor, In focus, video sebagai sarana ketika memberikan materi pelatihan. Selain itu peserta juga akan diberikan buku yang berisi materi yang akan diberikan, buku tulis untuk mencatat, serta alat-alat tulis lainnya.

\section{Pelaporan}

Langkah terakhir yang dilakukan adalah membuat laporan dari keseluruhan kegiatan pengabdian masyarakat "Kiat Membangun Karakter Anak" yang telah dilakukan. Disamping itu, akan dilakukan juga evaluasi terhadap kegiatan dengan memberikan pertanyaan mengenai tanggapan peserta pelatihan mengenai pelatihan yang telah diberikan tersebut.

\section{HASIL DAN PEMBAHASAN}

\section{Gambaran Pelaksanaan Pelatihan}

Pelatihan "Kiat Membangun Karakter Anak" ini direncanakan akan diberikan kepada 90 orangtua yang mempunyai anak yang bersekolah di TK Raudlatul Azhar. Namun pada hari pelaksanaan kegiatan peserta yang hadir hanya 48 orangtua, karena kegiatan dilakukan pada hari kerja dan sebagian besar orangtua bekerja.

Pemateri pada sesi kedua ini adalah Radhiya Bustan, M. Soc, Sc. Adapun tema yang diangkat pada sesi ini adalah "Membangun Karakter Anak" (Materi terlampir). Pertemuan ini dilaksanakan pada tanggal 02 Mei 2016 di Aula TK Raudhatul Azhar.

Sebelum memulai materi, pembicara mengajak orangtua siswa untuk berdiskusi terkait caracara mendidik karakter anak yang sudah mereka lakukan saat ini, bagaimana kendala yang dihadapi dan apa tindakan yang dilakukan untuk mengatasinya. Beberapa orangtua menyampaikan bahwa mereka mendidik anak lebih dominan dengan memberikan nasehat, apabila anak tidak mendengarkan, orangtua kerap kali merasa tidak mampu menahan emosinya dan akhirnya memarahi dan membentak anak. Melalui proses diskusi tersebut terlihat bahwa sebagian besar orangtua belum dapat memahami perkembangan anak, sehingga belum mampu memaksimalkan caracara efektif untuk mendidik karakter anak sesuai tingkat perkembangan mereka, seperti dengan memberikan contoh, membacakan cerita/kisah Nabi, membentuk emosi positif dengan cara bermain bersama, dan lain sebagainya.

Karakter dalam Islam disebut juga dengan akhlak. Akhlak termasuk didalamnya adab 
yang meliputi pembiasaan, keteladanan, dan disiplin. Akhlak Rasulullah SAW adalah contoh teladan bagi umat Islam, sehingga perlu diperkenalkan kepada anak sejak dini. Dengan mengetahui sifat-sifat dan akhlak Rasulullah SAW, diharapkan anak-anak dapat mencontoh dan meneladani akhlak Rasulullah dalam kehidupan sehari-hari. Untuk itu, materi yang disampaikan oleh pembicara banyak membahas terkait karakter dan akhlak Rasulullah sebagai contoh teladan bagi umat Islam, sebagaimana Firman Allah SWT dalam surat Al Ahzaab ayat 21 yang artinya sebagai berikut:

"Sesungguhnya pada diri Rasulullah ada teladan yang baik bagimu, yaitu bagi orang yang mengharap Allah dan hari akhir serta banyak berzikir kepada Allah" (QS. Al Ahzaab: 21)

Pembicara kemudian mengajak orangtua untuk mendengarkan kisah, film ataupun berdiskusi terkait tema-tema akhlak Rasulullah sebagai berikut:

1. Menjauhi sifat marah

2. Tidak suka mengadu domba

3. Tidak mencemooh

4. Tidak pernah sombong

5. Menjauhi sifat hasad

6. Menebarkan salam

7. Tenang dan tidak terburu-buru

8. Senang menolong

9. Menjaga shalat berjamaah ke masjid

10. Tidak berburuk sangka

11. Mencintai sesama

12. Menjaga amanah dan jauh dari sifat khianat

13. Menghormati yang lebih tua

14. Menjaga kebersihan

15. Menebarkan senyum, tidak bermuka masam dan perhatian kepada teman

16. Menjauhi permusuhan

17. Selalu rendah hati

18. Meninggalkan perbuatan curang tipu muslihat

19. Tidak pernah berdusta, berkata keji, dan melakukan ghibah

20. Selalu berdo'a setiap ingin melakukan seusatu

21. Bersikap lembut dan tidak kasar

22. Sangat pemaaf

23. Pemurah (dermawan)

24. Kuat dan berani membela kebenaran

25. Menyayangi binatang

26. Bermanfaat bagi orang lain
Dalam pembahasan tema-tema tersebut, didiskusi cara-cara efektif yang dapat dilakukan orangtua dalam menanamkan karakter atau akhlak Rasulullah tersebut. Mulai dari membangun kedekatan emosional dengan anak agar menimbulkan emosi positif.

Membangun kedekatan emosional dengan anak dilakukan melalui komunikasi efektif, melalui cara antara lain sebagai berikut:

1. Menggunakan kata "minta" saat kita meminta anak untuk melakukan sesuatu

2. Menatap mata anak ketika kita berkomunikasi dengannya

3. Menyertai komunikasi dengan kontak fisik

4. Menjadi pendengar yang baik ketika anak sedang berbicara

5. Mencintai anak dengan cara dia mencintai Orangtua diminta untuk mengevaluasi sejauh mana mereka sudah berkomunikasi efektif dengan anak-anak mereka. Sebagian besar orangtua mengaku masih belum mengaplikasikannya. Kemudian orangtua diminta memberikan contoh-contoh perilaku yang sudah pernah dilakukan selama ini dan yang akan mereka lakukan di rumah. Contohcontoh perilaku tersebut didiskusikan di dalam kelompok sehingga saling memperoleh masukan sesama anggota kelompok. Kemudian orangtua diminta dengan penuh komitmen untuk mempraktekkan di rumah.

Beberapa hal lain yang terkait dengan pengembangan kemampuan psikosial anak juga didiskusikan pada pertemuan tersebut, antara lain adalah:

1. Mengkomunikasikan cinta dengan katakata penuh kasih sayang, pujian, dorongan yang membesarkan hati, bimbingan, panggilan "sayang" yang baik kepada anak

2. Memberikan hadiah

3. Melayani anak dengan memberikan contoh sampai dia mampu, seperti mengajari anak melayani diri sendiri dan orang lain

4. Bersahabat dan bersenda gurau dengan anak

5. Memberikan sentuhan fisik

6. Memenuhi keinginan anak secara bertahap

Pengembangan psikososial anak perlu dilandasi dengan ajaran agama agar anak mempunyai karakter Islami yang sesuai dengan tuntunan agama. Adapun hal-hal yang dapat dilakukan orangtua adalah: 
1. Membangun kejujuran dan membiasakan anak agar menjaga rahasia

2. Membangun kepercayaan sosial melalui pembiasaan membantu orang tua, bergaul dengan teman sebaya, empati

3. Membangun kepercayaan ilmiah dengan mulai dari mengajarkan Al-Qur'an dan Hadits Nabi yang merupakan sumber pengetahuan

4. Membangun jiwa entrepreneur sebagaimana yang dicontohkan oleh Rasulullah.

Contoh-contoh yang dilakukan Rasulullah dalam mendidik anak menjadi suri tauladan juga bagi para orangtua dalam mengembangkan karakter positif pada anak mereka.

Pada akhir sesi dilakukan tanya jawab dengan orangtua untuk memperkuat materi yang sudah diberikan agar dapat dipahami dengan baik. Pertanyaan yang disampaikan terkait kiat praktis dalam membangun karakter anak (seperti membangun karakter disiplin anak yang susah bangun pagi, shalat, merapikan mainan sendiri, dll). Pembicara kemudian memberikan jawaban merujuk kembali pada isi materi pelatihan, kemudian memberikan contoh praktis yang bisa dilakukan orangtua di rumah.

Sesi kedua pelatihan dilakukan kepada guruguru TK Raudlatul Azhar. Pelatihan pendidikan karakter di TK yang diikuti oleh 11 guru-guru TK Raudlatul Azhar ( 1 orang guru berhalangan hadir karena melahirkan) dilaksanakan pada hari Sabtu, 25 Juni 2016 mulai pukul 08.30-10.30. Kegiatan pelatihan karakter diawali dengan diskusi mengenai karakter dan kegiatan apa saja yang sudah dilakukan di TK. Setelah mengawali kegiatan tersebut dengan diskusi maka guru-guru TK Raudlatul Azhar menyadari bahwa banyak sekali nilai-nilai karater yang belum diterapkan. Dalam hal ini guru-guru TK mengatakan bahwa sudah lama mereka mengetahui tentang pendidikan karakter tetapi tidak memahami bagaimana pelaksanaannya di TK. Untuk itu ibu Nila Fitria, M.Pd selaku narasumber memberikan penjelasan mengenai apa itu karakter, pendidikan karakter, tujuan pendidikan karakter, nilai-nilai pendidikan karater anak usia dini, peran pendidik dalam pendidikan karakter, dan perencanaan pendidikan karakter. Setelah pemberian materi oleh Ibu Nila, maka dilanjutkan dengan tanya jawab. Ibu May selaku Kepala TK Raudlatul
Azhar bertanya bagaimana menghadapi guru yang sulit sekali bekerjasama dengan guru-guru lainnya? kemudian Ibu Nila menjawab bahwa setiap guru yang hadir disini sudah membawa karakternya masing-masing yang merupakan hasil pendidikan orangtua, guru, dan lingkungannya di masa yang lalu. Ketika seorang guru sudah berada di lingkungan yang baru contohnya sekolah, maka sebaiknya gru tersebut mampu beradaptasi dengan lingkungan yang baru. Salah seorang guru juga bertanya Ibu Anis, bagaimana menghadapi karakter anak yang suka berkata tidak baik? Ibu Nila pun menjawab, hal yang harus dicermati guru pertama kali adalah bertanya kepada orangtuanya mengenai rutinitas yang dilakukan anak tersebut di rumah. Kemudian lakukan kunjungan rumah (visit home) dengan maksud guru menyamakan data sesuai hasil perbincangan dengan orangtua. Biasanya bila hal tersebut sudah dilakukan, guru dapat melihat perilaku anak yang suka berbicara kotor itu dipengaruhi oleh siapa?

Kegiatan pelatihan pendidikan karakter pada guru-guru di TK diakhiri dengan foto bersama dan pemberian cinderamata kepada pihak sekolah. Harapan dari kegiatan ini adalah guru sudah dapat membuat perencanaan pendidikan karakter dan menerapkan dalam kegiatan belajar mengajar.

\section{Evaluasi}

Peserta dibagikan kuesioner terkait evaluasi efektivitas pelatihan. Kuesioner tersebut dibawa pulang dan diisi di rumah. Setelah 2 minggu, kuesioner baru dikumpulkan agar dapat melihat sejauh mana orangtua memperoleh manfaat dari pelatihan, apakah sudah dapat memahami materi dan kemudian mengaplikasikannya di rumah pada anak-anak mereka atau belum. Adapun hasil kuesioner menggambarkan bahwa: 
Tabel 1. Hasil Evaluasi Efektifitas Penelitian

\begin{tabular}{|c|c|c|}
\hline No & Aspek Penilaian & $\begin{array}{c}\text { Presentase Jawaban } \\
\text { "YA" }\end{array}$ \\
\hline 1 & $\begin{array}{l}\text { Kesesuaian materi dengan kebutuhan } \\
\text { orangtua }\end{array}$ & $90 \%$ \\
\hline 2 & $\begin{array}{l}\text { Materi pelatihan mudah untuk } \\
\text { dimengerti }\end{array}$ & $88 \%$ \\
\hline 3 & $\begin{array}{l}\text { Penetapan waktu pelatihan sesuai } \\
\text { dengan keinginan }\end{array}$ & $85 \%$ \\
\hline 4 & $\begin{array}{l}\text { Menimbulkan motivasi untuk } \\
\text { membentuk pola baru dalam mendidik } \\
\text { anak }\end{array}$ & $88 \%$ \\
\hline 5 & $\begin{array}{l}\text { Perubahan sikap dalam mendidik anak } \\
\text { setelah mengikuti pelatihan }\end{array}$ & $90 \%$ \\
\hline 6 & Memperoleh pengetahuan baru & $90 \%$ \\
\hline 7 & $\begin{array}{l}\text { Hubungan ibu dengan anak menjadi } \\
\text { lebih baik }\end{array}$ & $90 \%$ \\
\hline 8 & $\begin{array}{l}\text { Menjadi lebih bersemangat menjalani } \\
\text { hari-hari sebagai orangtua }\end{array}$ & $90 \%$ \\
\hline 9 & $\begin{array}{l}\text { Sudah mulai mempraktekkan } \\
\text { pengetahuan yang didapat dari } \\
\text { pelatihan }\end{array}$ & $85 \%$ \\
\hline
\end{tabular}

Berdasarkan tabel diatas diperoleh gambaran bahwa hampir $90 \%$ peserta pelatihan, yaitu orangtua siswa TK Raudhatul Azhar berpendapat bahwa kegiatan pelatihan "Kiat Membangun Karakter Anak" memberikan dampak positif bagi mereka dalam mendidik dan membangun karakter anak.

Hasil kuesioner juga diperkuat dengan kunjungan rumah secara random kepada 3 orang peserta. Tujuannya adalah untuk triangulasi data dengan mengobservasi dan memperoleh informasi dari pihak keluarga apakah peserta pelatihan sudah mulai menerapkan kiat-kiat membangun karakter anak di rumah masing-masing. Dari 3 rumah yang dikunjungi, diperoleh hasil bahwa 2 orang sudah mulai mencoba menerapkan cara-cara positif dalam berkomunikasi dengan anak, mulai dari hal yang sangat sederhana. 1 orang masih belum mampu mengaplikasikan karena masih sulit mengontrol emosi dan merubah kebiasaan memarahi anak. Namun yang bersangkutan berjanji akan berusaha untuk memperbaiki dan merubah kebiasaan tersebut. Informasi ini juga dibenarkan oleh anggota keluarga yang berada di rumah ketika itu.
Adapun hasil kuisoner $90 \%$ guru TK akan merancang untuk membuat program pembelajaran berbasis karakter dan $90 \%$ guru TK Raudlatul Azhar akan mempraktekkan pengetahuan yang diberikan di dalam KBM. Guru TK Raudlatul Azhar merasa memperoleh pengetahuan yang baru serta akan menajadi teladan untuk anak didiknya sebanyak $90 \%$. Penetapan waktu kegiatan sesuai dengan waktu yang diinginkan, dimana guru TK Raudlatul Azhar dalam masa libur sekolah dan akan mempersiapkan awal tahun ajaran. Sebanyak 90\% guru bersemangat untuk mengajar setelah mendapat pengetahuan.

\section{KESIMPULAN DAN SARAN}

\section{Kesimpulan}

Berdasarkan pengabdian masyarakat yang sudah kami lakukan yaitu berupa pelatihan "Membangun Karakter Anak" yang diberikan kepada 48 orangtua siswa dan 12 orang guru, diperoleh hasil bahwa pelatihan terkait dibutuhkan oleh orangtua, terlihat dari hasil evaluasi yang diisi oleh orangtua bahwa hampir $90 \%$ orangtua merasa memperoleh pemahaman terkait membangun karakter anak dari materi pelatihan. Namun baru sekitar $85 \%$ orangtua yang sudah mulai menerapkan materi tersebut. Begitu pula dengan hasil evaluasi yang diperoleh dari guru TK Raudlatul Azhar. Bahwa 90\% guru TK memperoleh pengetahuan tentang rancangan dan pelaksanaan kurikulum berbasis karakter dari materi pelatihan. Hal ini juga diperkuat dari hasil kunjungan rumah yang dilakukan secara random ke rumah 3 orang peserta pelatihan.

\section{Saran}

Berdasarkan hasil tersebut, maka saran untuk kegiatan selanjutnya agar lebih banyak ditambahkan materi praktek dan tugas rumah yang dievaluasi secara berkala. Mengingat pemahaman teoritisnya sudah diberikan pada pertemuan tersebut. Selain itu, diharapkan pelatihan membangun karakter juga diberikan kepada orangtua laki-laki, agar pola asuh di rumah dapat konsisten dan dijalankan dengan penuh komitmen bersama-sama antara orangtua dan pihak sekolah. 


\section{DAFTAR PUSTAKA}

[1] Ansori, Muslim dkk. 2007. Pendidikan Karakter Wirausaha. Yogyakarta: Andi

[2] Brooks, Jane B. 1991. The Process of Parenting. $\quad 3^{\text {rd }}$ edition. Mayfield Publishing Company.

[3] Henniger, Michael L. 2013. Teaching Young Children: An Introduction. Pearson

[4] Martin, A. Carole \& Karen K. Colbert. 1997. Parenting: A Life Span Perpective. McGraw-Hill Companies, Inc

[5] Morrison, G.S. 2012. Dasar - Dasar Pendidikan Anak Usia Dini (PAUD). Edisi Kelima (terjemahan). Jakarta: Indeks
[6] Papalia, Diane \& Ruth D Feldman.2013. Experience Human Development 12ed. McGraw-Hill International Edition

[7] Patmonodewo, Soemiarti. 2000. Pendidikan Anak Prasekolah. Jakarta: Depdikbud \& Rineka Cipta

[8] Wibowo, Timothy. 2012. Rahasia Sukses Pendidikan Karakter: 7 Hari Membentuk Karakter Anak. Jakarta: PT. Grasindo.

[9] Muhammad, Muzdalifah \& Yansyah, Luthfi. 2013. Mengenal Karakter dan Akhlak Rasulullah SAW. Jakarta: Zikrul Hakim.

[10] Aunillah, Nurla Isna. 2015. Membentuk Karakter Anak Sejak Janin. Yogyakarta: Flash Books 